\title{
On the Path of the Prophet in Unsettled Times: Sudan's Republican Brotherhood Looks Abroad
}

\author{
Steve Howard
}

check for

updates

Citation: Howard, Steve. 2021. On the Path of the Prophet in Unsettled Times: Sudan's Republican Brotherhood Looks Abroad. Religions 12: 100. https://doi.org/10.3390/ rel12020100

Academic Editors: Ousmane Kane and Zekeria Ould Ahmed Salem

Received: 21 December 2020

Accepted: 28 January 2021

Published: 2 February 2021

Publisher's Note: MDPI stays neutral with regard to jurisdictional claims in published maps and institutional affiliations.

Copyright: (c) 2021 by the author. Licensee MDPI, Basel, Switzerland. This article is an open access article distributed under the terms and conditions of the Creative Commons Attribution (CC BY) license (https:// creativecommons.org/licenses/by/ $4.0 /)$
Media Arts, Ohio University, Athens, OH 45701, USA; howard@ohio.edu

\begin{abstract}
Mahmoud Mohamed Taha (1909-1985) founded the Republican Brotherhood in the early 1950s to promote social reform through a new understanding of divine revelation which had emerged during his two years of khalwa or retreat. From the 1950s through the 1970s, the Republican Brotherhood attracted a few thousand followers to Ustadh Mahmoud's teachings, whose foundation was the discipline of tariq Mohamed, "the Path of the Prophet." This Path was a challenging design for life that embraced gender equality and social justice against the backdrop of an increasingly Islamist-oriented Sudan. In the 1980s, the height of the Brotherhood's membership, the Republicans confronted Sudan President Gaafar Nimeiry's imposition of his version of "Islamic Law," with publications and street corner lectures. Through peaceful protest, the Republican's point was that Islamic Law would only be oppressive to the millions of non-Muslims in the country and to women. The result of this resistance was the 1985 arrest and execution of Taha for trumped-up charges of apostasy. In the decades following the passing of their teacher, the Republicans have kept a low profile in Sudan while trying to maintain both their faith and some social cohesion. In reaction to both the Islamist political conditions in Sudan and the failing economy, many Republicans have joined the Sudanese flight abroad, with modest communities of Republicans now established in the Gulf States of Qatar and UAE, as well as the United States. Through field work and interviews with members of these three communities, I have tried to understand the effort to sustain the discipline of the Path of the Prophet by Republican brothers and sisters under circumstances of the extremist orientations of Gulf politics, or the "moral ambiguity" of the United States. This study is part of a larger book project on the Republican Brotherhood following the execution of Ustadh Mahmoud.
\end{abstract}

Keywords: Islam; Africa; Sudan; Sufi movements; Arab Gulf; USA

\section{Introduction}

The popular uprising and the dramatic political changes in Sudan from December 2018 to July 2019 have emerged from the challenges to Sudan's religious order since the 1980s and earlier. While this uprising has been ostensibly secular in nature, it should be noted that because morality or spirituality enter virtually every Sudanese space, recent street-based political activity has been marked by a high state of consciousness as well. The protests have featured the chant in Sudanese Arabic, "silmiya, silmiya! Dhid al-haramiya!!" "Peacefully! Peacefully! (demonstrate) against the thieves!") ${ }^{1}$ as a moral reminder of the view from the street of the previous regime. The small but significant Republican Brotherhood founded by Mahmoud Mohamed Taha has been at the center of those changes-particularly in pricking the nation's consciousness - throughout this period of time. This era has also seen the departure of many Republican brothers and sisters from their beloved homeland. How the fikr jumhouria, "Republican ideology," has been preserved and practiced abroad is the subject of this paper, which is part of a larger project to examine how the members of the Republican movement have fared in the wake of the 1985 execution of their leader and spiritual guide. Sustaining the charisma of a dynamic teacher in his absence is certainly

\footnotetext{
1 Sudanese Arabic transliteration is used here instead of standard Arabic to convey the Sudanese nature of the research.
} 
at the core of the history of all of Sudan's many Sufi sects. But in the case of Mahmoud Mohamed Taha's Republican Brotherhood, in that an esoteric personal discipline is its essential essence, the removal of adherents from the familiar surroundings of Sudan to societies like the Gulf States or the United States provides tests to faith that may not have been considered. And the challenge of passing on this spiritual discipline to one's children while living abroad may be especially daunting. In many interviews with Republican parents-people who had been taught the Republican ideology in the presence of Ustadh Mahmoud-I learned that they missed his careful teaching style most of all.

This article is part of a larger project examining the lives of members of the Republican Brotherhood following the execution of Mahmoud Mohamed Taha in 1985. Over the past four years, I have conducted more than 100 interviews with brothers and sisters-followers of Ustadh Mahmoud-in Sudan, the United States, and in several countries of the Arab Gulf. Their willingness to participate in lengthy and repeated conversations with me in these locations is in part due to my long-term association with the movement. I first met Mahmoud Mohamed Taha in 1982. And I lived with a number of families who identify with Taha's philosophy for several years following that meeting and have maintained these relationships. My 2016 book, Modern Muslims, is an account of much of this period. I am a sociologist interested in the dynamics of small-scale Muslim social movements in Africa. Christianity, too, has fueled such movements on the continent, with charismatic leaders found in both. The sustained dynamism of the Republican Brotherhood, well past the execution of Mahmoud Mohamed Taha some 36 years ago, has also sustained my intellectual and emotional interest in their efforts over these decades. The Harvard conference at which this paper was first presented provided an excellent opportunity to reflect on the meaning of the Republican phenomenon outside of Sudan.

Mahmoud Mohamed Taha (1909-1985) was trained as an engineer during Sudan's colonial period at Gordon Memorial College, later the University of Khartoum, and became active in the Graduates Congress, the primary vehicle of Sudan's independence movement. In the 1940s, Taha jumped into the political fray himself, founding what he called the Republican Party to move towards replacing the British-Egyptian "condominium" with a Republic of Sudan. The context of this move was in that the two major parties at the time - the Ummah Party of the Mahdists and the Democratic Unionists of the Khatmiya Sufi tariqa-had, in Taha's view, non-republican designs on post-condominium Sudan. The Mahdists intended to establish a hereditary administration with rule by the descendants of the 19th century's Mahdi, and the DUP was promoting union with Egypt. By 1945, it was clear that these two political party leviathans would attract the votes of their Sufi followers and crowd out any other political organization. Taha set politics aside at that point in order to engage in social reform.

Taha's activism continued in his home town of Rufa'a on the Blue Nile when a woman was arrested by the British colonial police for circumcising her young daughter. This ancient and pre-Islamic practice had been outlawed by the British colonial authorities several years earlier. Taha led a demonstration at Friday prayers following the woman's arrest and was himself taken into custody. Taha's point in demonstrating was that the colonial anti-FGM law was pointless in that the ancient practice would not disappear until women were treated as equals to men in Islamic practice, and had access to education. Taha spent several months in jail for his offense and upon his release took to a khalwa (Sufi-inspired retreat) in Rufa'a. He emerged after two years with his new understanding of divine revelation. The essence of that interpretation was to distinguish and operationalize the Qur'anic revelation from the Meccan phase of the Prophet Mohamed's prophecy from the Medinan phase, with the latter speaking specifically/exclusively to the disruptive social period of the resettlement of the Muslims in Medina and the Meccan texts speaking to all of Mankind through all of Eternity. This was certainly not a new understanding of Qur'anic revelation but, throughout Ustadh Mahmoud's career, he and his followers were frequently condemned by those who viewed this interpretation as jettisoning half of the Qur'an. In Mahmoud's view, the Meccan revelations of the Qur'an also provided the Path or ibada (personal practice) of the Prophet 
himself. "The Second Message of Islam," based on these revelations, became the thesis for Taha's teachings and from the 1950s to the 1970s, Taha's popularly named "Republican Brotherhood" (after his political party) attracted a few thousand followers from all parts of Sudan. The foundation of Ustadh Mahmoud's teachings was the discipline of tariq Mohamed, "the Path of the Prophet." These teachings presented a challenging design for life that embraced gender equality and social justice against the backdrop of an increasingly Islamistoriented Sudan. Taha published his book, The Second Message of Islam (Taha [1964] 1987) in the same year Sayid Qutb, the radical Egyptian member of the Muslim Brotherhood, published his well-known book, Milestones (Qutb 1990).

That modernist, progressive Islamic thinking could emerge from Sudan, a Black African country dismissed by orientalists such as Trimingham (1949) as existing on the "Islamic fringe," despite Sudan's proximity across the Red Sea from Mecca, continues to be the dominant mode by which both Western scholars of Islam and rujal-al-din ("religious scholars") thinkers of the Muslim world itself consider the differentiation of Muslim practice in Sudan. This is an important reason for the ideas of the Republican Brotherhood to be considered in a more global context. At the same time, that both Ustadh Mahmoud and his followers did not embrace the label of Sufism for their movement makes it more difficult to situate the Republican Brotherhood in the literature.

While Sudanese people have been enthusiastic participants in Sufi tariqas since the coming of Islam to Sudan in 15th and 16th centuries (McHugh 1994), with the Qadariyya and the Shadhiliyya orders among the earliest Sufi orders to be established (Karrar 1992), the Republicans felt that Sufism had too much of an investment in ritual and adherence to personal relationships with a shaykh. Republicans often referred to these practices as "dhikir bidun fikr" or 'remembering God without thinking.' Of course, most Republican brothers and sisters came from families that had practiced Sufism for generations, and Republican ritual itself was marked by Sufi-inspired characteristics, such as collective chanting of the name of God, or singing odes (qasaid) in praise of Prophet or God. But Republicans rejected adherence to taifia - sectarianism - which they felt had both deteriorated Sufi devotion and politicized Sufi organizations in Sudan.

Ustadh Mahmoud's followers called him "teacher," and many of them would arrange their day or indeed their entire lives in order to spend as much time listening to him as possible. There were daily before-work meetings with Ustadh Mahmoud at this home which also served as the movement's Center, and there were evening meetings as well. Those brothers and sisters who lived outside of Khartoum might come to the capital for the weekend or over school holidays and spend the whole time near their teacher. Taha's books were studied individually and in groups, and quotes from some of them were turned into posters which decorated the homes of Taha's followers. He offered spiritual guidance in a gentle manner, particularly through prayer and deep study of the Qur'an. His followers were and still are a group of seekers of knowledge. "I found what I needed in the fikr, (the Republican ideology)" a brother told me who had been born after the execution of Ustadh Mahmoud. "It has helped to solve my problems."

As Daniel Martin Varisco wrote, Islam is "an eminently textualized faith"3. . Mahmoud Mohamed Taha ([1964] 1987) provided contrast to the conventional Islamist perspective in his own Qur'anic commentary, his book, The Second Message of Islam. He also encouraged his followers, particularly women, to study the Qur'an. In his book may be found an Islamic reform "how-to": an activist (many said, "too activist") approach or methodology that acknowledges the historical process of Qur'anic revelation and provides direction to the message of God that Taha believed was meant for the modern world. Taha did not seek accommodation between Islam and the latest Western mores; he wrote that his reading of the Qur'an found democratic values and social equality in places of honor". "We are not

2 Interview with Osama Mohamed Ali Khartoum, December 2018.

(Varisco 2005, Islam Obscured, p. 152).

4 (Howard 2016a, Modern Muslims, p. 46). 
concerned here with deprecating Western civilization or belittling it, but rather wish to study it scientifically and put it in its proper place. We wish to acknowledge its advantages and advocate its reform so that it evolves into a true civilization rather than remaining satisfied with its material progress" ${ }^{\prime 5}$ (Taha 1975).

From the 1960s into the 1980s, Mahmoud Mohamed Taha was denounced regularly from Sudan's government-controlled pulpits. He was arrested and tried several times for apostasy and his books-individually and collectively-were banned from sale in Sudan. His teachings became known in the region, with Imams from Al Azhar to Riyadh denouncing him as well. Saudi Arabia also took the step of forbidding Taha from entering the country, while at the same time Taha taught his followers that they should avoid making the religious obligation of the Haj pilgrimage until it was an affordable excursion for all Muslims. Such denouncements also fueled speculation in Sudan and elsewhere that Ustadh Mahmoud was sponsoring salacious activities, particularly in that his work had a strong focus on improving the status of women in Islam (Howard 2016b).

In the 1980s, at the height of the Brotherhood's membership, the Republicans confronted Sudan President Gaafar Nimeiry's imposition of his version of "Islamic Law," with publications and street corner lectures. The Republicans had been banned by the Sudan government from the broadcast airwaves earlier. Through small peaceful protests in the streets, the Republicans' point was that Islamic Law would only be oppressive to the millions of non-Muslims in the country and to women. Their credo was the Qur'anic verse from Surat-al-Baqarah (256), la ikrah f'il deen ("no compulsion in religion"), that God is obeyed as He speaks to one's heart. The result of this resistance was the 1984 arrest and 1985 trial and public execution of Taha on trumped-up charges of apostasy.

Some Republican brothers and sisters had of course traveled abroad before the execution of their teacher, Mahmoud Mohamed Taha. Taha had encouraged his followers, particularly the sisters, to get as much education as they possibly could. A handful of them had made it to the UK especially for advanced degrees or other training opportunities. Those who returned from abroad were usually welcomed with a jelsa, a meeting "seating" of the Brotherhood at the home of Ustadh Mahmoud, where they would share impressions (al-intiba'at) of the foreign experience with a typical reductive emphasis on "how the West was great but clearly lacking in spiritual development." The travelers were inevitably questioned about foreign/Western reaction to their Republican ideology in that there was an expectation that one would find a way to communicate knowledge of Ustadh Mahmoud's teachings formally or informally while abroad.

The best-known Republican innovation imported from a brother's trip abroad that ultimately assisted dawa or the propagation of the Republican ideology in Sudan was the mimbar or "public-speaking platform." Dr. AbdelRahim A-Rayah, who had gone in the 1970s for training in political science in the UK, had admired the "Speaker's Corner" that he had witnessed in London's Hyde Park. There, anyone could reserve the spot and speak to whatever audience was attracted to the speaker's agenda. The Republicans began using this technique all over urban Sudan to spread awareness of Ustadh Mahmoud's teachings, although the Republican intent in presenting a platform was more about developing the inner awareness of the speaker-brother or sister-over the goal of recruiting new Republicans. They lived and expressed devotion to God rather than slavish adherence to sharia. Such issues were expressed and explored in the public talk or mimbar which became particularly popular both on university campuses and daily under a large aradeb (tamarind) tree in downtown Khartoum. During Numeiry's crack-down on the Republicans in the period 1983-1984, Republican brothers and sisters were actually arrested while in the act of presenting these platforms in the Khartoum area (Howard 1986).

President Jaafar Numeiry was overthrown by Sudan's popular intifada (uprising) on 7 April 1985, three months after he had executed Ustadh Mahmoud. A short period of democracy followed until Omer ElBashir's coup of 30 June 1989. While Numeiry had

5 (Taha [1964] 1987, The Second Message of Islam, p. 61). 
initiated Sudan's Islamist political orientations and had invited a diverse array of Islamists into his regime, Bashir, while himself not a committed Islamist, completely embraced the Muslim Brotherhood's positions and policies for his own as he quickly consolidated power. The early 1990s saw the implementation of Muslim Brotherhood tactics like the "ghost houses" (beyut al-ashbah) where opponents were tortured and even killed.

The Republican Brotherhood never had a detailed plan to propagate Mahmoud Mohamed Taha's message abroad, but happenstance and the words of Ustadh Mahmoud assisted in that process. No one assumed the mantle of leadership following Ustadh Mahmoud's execution-he did not have a khalifa, so the continuation of the movement became a personal commitment on the part of individual Republican brothers and sisters-its collective power had to be read from this aggregate. Taha wrote in The Second Message of Islam,

"In view of the consistent failure of human ideology to find the proper balance between the interests of the individual and those of society, we propose an alternative ideology, namely Islam. But this is not the partisan dogmatic call to Islam as a religion opposed to other religions. It is not even a call to religion as opposed to secular thinking. Our conception of Islam embraces other religions and secular sociopolitical theories in that it accepts and provides for the realization of the entire body of religions and human thinking6".

Taha and his followers spoke of this message as a "universal" one, so living it outside of Sudan could be seen as part of its natural progress. However, the sociopolitical/socioeconomic circumstances which led Republicans abroad were not necessarily spiritual in nature. There were firings and harassment at work for some under the Bashir ingaz ("salvation") regime and there were opportunities abroad that pulled Republicans to seek employment elsewhere. The crushing devastation of the execution of their teacher was also on the minds of many as they packed to leave Sudan, the eternal home of the Republican ideology and the embedded nostalgia of the perfection of the land and its people.

The economics of the region cooperated with Republicans seeking to leave Sudan as well. Since the "oil boom" of the 1970s, the poor Arabic-speaking countries have provided labor to the rich Arab oil-producing countries. The rich countries have not been able to provide all the skilled labor they need, and the poorer Arabic-speaking countries, Sudan, Egypt, Tunisia, Palestine, and Morocco, have engineers, accountants, pharmacists, teachers, and physicians who cannot find work at home. A later development that primarily attracted the next generation of Republicans was the phenomenon of US-sponsored wars in the region and the basing of non-Arabic-speaking troops there, particularly in Iraq, Qatar, and Saudi Arabia. I will first discuss the situation of Republican brothers and sisters in two countries, Qatar and United Arab Emirates, to give a sense of the mobility of the Republican ideology in the Arab world; the Republicans' American experience will follow.

\section{Qatar and United Arab Emirates}

Republican brothers and sisters have found a wide variety of employment in the Gulf State of Qatar. Positions held by Republicans in this small, wealthy country include physicians, psychiatrists, pharmacists, university lecturers, highway engineers, and service in Qatar ministries. The Udaid military base outside Doha is also the largest US military outpost in the Middle East housing some 11,000 US soldiers. Over the years of its existence, this base has employed several Republicans in key translator positions through US contractors.

The position of military translator also requires US citizenship/security screening, so this indicates that many of the Qatar Republicans are in that country through step migration. Earlier on, in most cases towards the beginning of Omar el-Bashir's regime in Khartoum, these Republicans had moved to the US, primarily for graduate degrees 
and/or seeking political asylum and became US citizens. While US citizenship is part of the security requirement for working on the military base, it also means that Sudanese employed in Qatar, and other Gulf States, may receive higher salaries than say other African nationals seeking jobs in the Gulf. Western qualifications earn higher salaries in the Gulf.

A prominent Republican Brother living in Qatar is Ahmed Almustafa Dali. Dali was well known on the University of Khartoum campus in the 1970s where he gave public talks about Mahmoud Mohamed Taha's teachings on a daily basis. The volatile Muslim Brotherhood faction on the university campus attacked Dali at one of these speaking events, leaving him partially deaf. But he continued this work in the center of Khartoum, attracting hundreds to his noon-time talk which was often a raucous affair and an informal forum for opposing points of view. Dali continues his public communication efforts from his perspective as a long-time student of Mahmoud Mohamed Taha, while hosting a weekly talk on Facebook about the Republican ideology, which attracts hundreds of viewers every week, many making negative comments about Taha's thought.

In the UAE, Republicans are employed in similar positions as Qatar, with additional opportunities such as in fire prevention, legal advisors, accountants and in the retail sector. There is also a smaller US military facility in Abu Dhabi where some Republicans are employed as translators under similar circumstances as the base in Qatar. I would estimate there to be approximately 25 Republican families in Qatar and 40 families in UAE.

That the Republicans working in the Gulf States (and there are some in Oman, Bahrain and Saudi Arabia, as well as a few formerly employed as translators for US military during the US-led invasions of Kuwait and Iraq) tolerate the restrictions placed on them under these Salafist regimes is both ironic and indicative of the difficult political economy at home. Republicans in Qatar and UAE must be very discreet about their religious orientation, but they do meet among themselves frequently - they are an extended family after all. And any Republican gathering at the home of one of their number, or a picnic in some pleasant spot, will be just for Republicans and may include the singing of their hymns—gasaid — which are major features of Republican events at home as well in the post-Ustadh Mahmoud era. Their situation is made easier by the fact that the Arab societies of the Gulf are closed with few-to-no invitations made to outsiders to visit their homes. A colleague from work may invite one to a wedding nikah, at a hotel or some other neutral location, but these are male-only events which do not include prayer beyond the reading of the Fatiha, the opening verse of the Qur'an often used to seal a marriage.

The Republicans in the Gulf live comfortable, if modest, lives, in cities where the emphasis in popular image is on living over-the-top luxe lives. Saving some money to send home remittances, of course, and for the most part filling their religious obligations in a strange land is their focus. But in guarded, private conversation, Republicans will readily describe the Salafist regime under which they live and work, and its attendant contradictions - the opulent lifestyles making any religious proclamation by governments or individuals not credible. They will also describe the hypocritical denouncements of "Islamic terrorist" attacks in the West made by people in the Gulf States who at the same time make financial contributions to such cells. In conversations with Republicans, no Gulf person will be identified necessarily as participating in this kind of activity, and lowered voices or declarations that "this impression or knowledge of mine is just between us" also characterize these discussions. The Republicans residing as guests in these Muslim Gulf states recognize that their hosts find their views of Islam essentially heretical and the feeling is mutual at best.

In Sudan, the Republican sisters are distinguished by their adoption of the white taub, an enveloping light piece of cloth worn over a dress, as their uniform. It is a simple garment, associated primarily with school teachers and office workers, or was so particularly 20 years ago or more. But when I asked a sister in Doha why she and her colleagues did not wear the white taub there, she said "it has no meaning here; no one here understands why we would wear it." Newcomers, however, are seen in white, in stark contrast to Gulf women, normally enveloped head-to-toe in somber black. 
While Republicans acknowledge that much of Mahmoud Mohamed Taha's thinking was heavily influenced by Sufi masters of the past such as Nablusi, AbdelGadir Jailani or Ibn Arabi-and the words of those thinkers feature centrally in the Republican gasaidthey do not necessarily think of themselves as a Sufi order. Their view has been that the Sufis-such a very prominent aspect of Sudanese Islam — had lost their way with the Sufi emphasis on ritual and ritualistic obeisance to one shaykh. Republicans like to say that conventional Sufi practice is largely dhikir bidun fikr "remembering God without much thought." But in that it is challenging for outsiders to sort out the difference between them and Sudan's mainstream Sufis, it does give them pause when they hear denouncements of Sufis by the governments under which they live-with an emphasis on condemning shirik, "idolatry" from pulpits and ministries in those countries. Criticism of Sufi practice is to be expected in these nations where religious tolerance is not respected or observed.

Republicans in both Qatar and UAE have their children with them in many cases. It is expensive to educate them in that the preference is for international/English medium schools where din does not have a big role in the curriculum. In UAE, once foreign male children are out of school and not working, they must leave the country; a policy that does not apply to daughters. And the Republican parents worry about the atmosphere, the malls and life lessons taught there-you get what you buy.

Republicans in Dubai, the largest city in UAE, complain of the racism they experience in the country, and other types of discrimination. Sudanese and other non-nationals are referred to as muquym (residents) as opposed to mwatin (citizen). And there is an attendant expectation that mwatin have of muquym that the latter move out of the way when the mwatin passes. But of course, this pales against the knowledge that they are living in a country whose government cooperated with the regime in power in Sudan that has so oppressed them for their dedication to Ustadh Mahmoud's teachings. Conversations often turn to the subject of immigrating to Canada, a nation understood to be a land which respects freedom of expression and religion, and which is still encouraging immigration.

Reflecting on his life as a Republican working abroad, a brother in Abu Dhabi told me in 2019,

"I really miss chatting with brothers. In my Sudan life that was a daily part of my routine. Here the nature of the work of everybody in addition to the dense traffic/distance makes it difficult to visit/gather with brothers and sisters. Also we cannot have discussions about al-fikra \{the Republican ideology\} and share inshad \{the poetry of the group\} especially in open or public areas. Our group meetings are generally confined to cramped apartments.

Our apartments on the other hand, lack the gardens where one could do wadu (ablutions) as is prescribed in (Taha's book) Risalt al-Salah ${ }^{7}$.

Also, maybe for spiritual reasons, Qyam (the Prophet's prayer at night) is not easy to perform here, added to that, the difficulty of saying your 5 prayers on/in time.

A third dimension, which could be personal is that there is an abundance of food here, including fast food restaurants. On the one hand consuming a lot of food is NOT OK in al-tasawuf \{Sufism\} generally and in al-fikra (the Republican ideology) in particular. And the wasted food I see- dumping the left-overs while there are so many living in poverty- always makes me like not a good Jamhouri" ${ }^{\prime \prime}$. (Republican)

\section{USA}

A 2020 film by Bentley Brown (2020), Revolution from Afar, explores the perspectives of young Sudanese living in the US as they consider what happened in the revolution/overthrow of President Bashir in 2019. They wrestle with their identity and

\footnotetext{
7 Republicans generally avoid the common practice of performing ablutions in a bathroom.

8 Communication with Abdalla Osman, Abu Dhabi, April 2019.
} 
contemplate the helplessness they feel in not being present for this massive social change in Sudan. In looking at the movement of Republican brothers and sisters around the world, the followers of Mahmoud Mohamed Taha in the United States represent something of an enigma. American society offers both abundant obstacles and abundant opportunities to the Republican with intentions of engaging in the Islamic imperative of proselytizingextending the faith in new directions. The opportunities of course lie in the openness of American society to new ideas about religion, and the eagerness of many Americans to at least hear about alternative ways to approach the Divine. And the American constitution and rule of law are supposed to guarantee freedom to engage in such proselytizing. And the young people, the young Republicans, try to understand their parents' deep experience of Mahmoud Mohamed Taha and his teachings, which is not replicable in the US, or in Sudan for that matter.

On the other hand, the increasing secularity of America, combined with ever-present "Islamophobia," particularly since 9/11, may dampen the enthusiasm for launching any kind of attempt to introduce Mahmoud Mohamed Taha's apparently obscure message in the USA. Nevertheless, over the years of the Republican brotherhood presence in the US, there have been a variety of efforts to at least raise awareness of the Taha message, usually presented in the context of not correcting Western misconceptions about Islam, but of presenting the Republican ideology as a stand-alone truth about what the Qur'an and Prophet Mohamed explained to humanity in the seventh century. A moderate, nonextremist interpretation of Islam is central to Republican understanding.

Republicans also experience the tension in the US of the current atmosphere around the "immigration issue" that dominates headlines and the political discourse. Many of them sought asylum in the United States, particularly since Bashir's coup in 1989, and a few converted student visas into permanent residence. A Washington DC-based attorney developed a specialty in getting Republicans through the asylum application process, and is still invited to their social occasions. There was a period when many non-Republican Sudanese claimed to be followers of Mahmoud Mohamed Taha in order to apply for asylum and sought affidavits from members of Ustadh Mahmoud's family to support such claims. Poverty has also been an obstacle for fulfilling lives in the United States where the expense of living and the financial demands from home mean that some have needed to delay further training or higher education in order to send money home, which in turn impedes advancement in the US. Some Republicans have started their US lives on food stamps and or in subsidized Section 8 housing.

With limited financial resources and no formal infrastructure for the movement in the United States, opportunities for disseminating the Republican message are generally small in scale. Personal encounters with work colleagues, neighbors, friends are the mode, sometimes accompanied by the offer of one of the Republican books in English. The format may be the invitation/lure to try "Sudanese food" with one's family or an invitation from one Republican to join him/her at a Republican picnic, wedding, etc., in the area. Again, in every instance, the emphasis is on extending the Republican individual's confidence in communicating the ideology over planning for new membership. Every Republican living in the US has encountered an exuberant American interested in what they have been told about Taha's "liberal approach" to Islam. None have actually embraced Islam as a result of these encounters to my knowledge, and the friendly American attitude is one generally, as Republican brother and Emory University law professor Abdullahi An-Na'im interpreted it to me, of "that Republican ideology sounds like a good thing for you Muslims to observe but is not deeply appealing to me personally."

Dr. Abdullahi Ahmed An-Na'im is probably the most prominent member of the Republican Brotherhood living in the United States. He came to the US soon after the execution of his teacher and his own release from prison in Khartoum. He had gone to the police soon after the brothers and sisters began to be arrested in 1983 in order to offer legal support and was taken into custody himself. Today, he is a named chair at Emory University School of Law in Atlanta and a prolific writer on Islam and human rights issues. 
While An-Na'im represents himself as a student of Mahmoud Mohamed Taha, he does not focus on Taha's work in every element of his own writing, although he did publish the first English translation of Taha's main book, The Second Message of Islam (Taha [1964] 1987), a translation he completed while in prison himself. An-Na'im's dedication to his own scholarship has been an element of some contention between him and many other Republicans. The latter's view is that every Republican should be devoted to spreading the ideas of Ustadh Mahmoud. Abdullahi maintains his life as an academic while expressing deep admiration for his teacher's profound impact on his life. He wrote in 1986, “To have pursued his \{Taha's\} goals so selflessly and consistently for forty years, especially through his own personal life style, is an exceptional achievement. The example of this single man's living for and by his convictions, more than dying for them, is truly inspiring not only for Muslims but to all the people of the world." ${ }^{\prime 9}$

In locations with resources, such as university towns in the US-like Iowa City, Iowa or Athens, Ohio-larger Republican-themed events may be staged and built around the visit of a key member of the organization from Sudan or from another part of the US. This type of event may also take place in an urban center like Dallas, Texas or the Washington, DC area where there may be a larger Sudanese $j a$ 'alia (Sudan expatriates) and a larger number of Republicans in the community. Some of these large scale events in the US have had success in recruiting new Republicans-particularly young women who had come to the US with little prior knowledge of Taha's ideas. And in bigger towns, Republicans may stage an event or the local "Sudanese-American Organization" may host the event, which has its own implications for the improvement of Sudanese intersectarian relations-important in these tense times in the homeland. In the Washington suburbs, Sudanese-American community organizations rent permanent space to host such activities on a regular basis. In Monterey, California, at the Defense Language Institute, there are several Republicans teaching Arabic to American soldiers. They also regularly take advantage of the large group of other Sudanese there to invite them to programs where Republicans passing through town give talks on different elements of Republican thinking. The atmosphere, far from home on the Pacific Coast of the US, generates some kind of receptiveness to the discussion of approaches to faith. "We are Sudanese who spend all day teaching our language to a group of non-Muslim Americans," one Arabic teaching told me. "Coming together as Sudanese once and a while seems to help mitigate our differences."

The point of such public events is to (1) remind people, particularly other Sudanese, that the Republican Brotherhood is still active and ready to convey ideas of Mahmoud Mohamed Taha for a peaceful, democratic Sudan, and (2) to bring the attention of the general public to Sudan, which many feel is an obscure place in the US context. Finally, on public speaking, public presentations are very much part of the DNA of the Republican Brotherhood's operations. Such activity was shut down in Sudan following Taha's execution and revived to a limited extent in the US diaspora. The same applies to other Western countries where Republicans are found — on a smaller scale—such as the UK or Canada particularly. The January 18 anniversary of Ustadh Mahmoud's execution provides an important setting for annual gatherings in the US and for more discrete at-home observations in the Arab Gulf.

Of course, children of all ages are everywhere in any of these activities in the US. And the memory of any adult Republican brother or sister is focused on how they may have grown up playing with their fellow off-spring of Republicans on the fringes of a Republican event in Sudan, perhaps at the home of Ustadh Mahmoud. Republicans will relate with nostalgia their saying about these events, "every sister carrying Mahmoud and amoud," referring to the custom of naming first born sons after Ustadh Mahmoud and rhyming it with the name of the traditional traveling food container ("amoud"). While I am describing here the attempts of the Republican brothers and sisters to organize small-scale events to spread the message in the United States, any such activity is in the background

9 (An-Na'im 1986) "Mahmoud Mohamed Taha and the crisis in constitutional law reform," typescript. 
to the primary goal of raising children in this country. The main reality is that these are immigrants on relatively unsure footing in the US, uncertain of how to apply their Republican values to teach their children under the conditions of life in American society. In Sudan, the Republican Brotherhood was and is a family, functioning with its children in a "it takes a village mode." In the US, the village has distractions—ghafla—malls, abundant television, movie theaters, young friends with cars, schools jammed with after-school activity and so forth-all of which presents a steep learning curve for immigrant parents to navigate. The parents are also not in the best position to provide their children with information about college selection/career choices, etc., which may have the effect of children not meeting their potential. In many cases, these are one-parent families with the other parent stuck in Sudan for one reason or another and forced to do all of his/her parental interventions long distance (read: WhatsApp).

Discipline is a core Republican value, both in the Arabic sense of tarbia, "training," and in the sense of providing the atmosphere for one's children to learn right from wrong. Immigrant parents' limited experience of the mores of American culture, or that their children learn those mores faster than they do, results in many difficult challenges for these families. Some of the Republican offspring will admit to drug and alcohol use, as well as to having pre-marital sex, although their parents have not discussed this behavior with me. The children and their parents are also dealing with identity issues in the US as they never had to in Sudan, particularly around the issue of "being Black." This may be an issue for Sudanese living in the Gulf as well, but of course the US discussion is regularly on the nation's front pages, whereas in the Gulf there are few opportunities to air this type of grievance. A young Republican woman who came to study with me at my university told me, "We come here Steve and learn for the first time that we are African," which further complicates adjustment issues. The discovery of "Africa" comes from exposure to the cosmopolitan space in the American university, not to mention the American immigrant community, of many, many nationals of other African countries. Finding space to focus on the spiritual in such contexts has much resonance with other African Muslim immigrant groups in the US such as the Somalis, whose large communities in the US are frequently dealing with these difficult issues across generations. However, the Republicans in the US and in the Gulf are guarded about their interactions with other Muslims, a characteristic of their lives in Sudan as well. Friday communal prayer at the home of Mahmoud Mohamed Taha during the time of the movement in the 1970s and 1980s was a critical element in holding the movement together. I see Republicans in Sudan and those abroad seize every opportunity they can to pray together when they can; even in a hospital lobby, for example, when several have met to visit someone who is ill. The Republicans ceased going to mosques for prayer in the 1970s when every imam in Sudan was denouncing them and their teacher, and Ustadh Mahmoud was teaching them how important it was to know the morality of the person in whom you are allowing to lead you in prayer.

The social adjustment issues common to any immigrant experience in the US combined with the close-knit nature of the community that the Republican Brotherhood built in Sudan, intensifies the membership's urge to belong as they establish their lives in the United States. A brother who lives in a distant corner of the country lost his wife unexpectedly to cancer at a relatively young age. Within $24 \mathrm{~h}$ of her death, a wafd (delegation) of Republican brothers and sisters from all over the United States arrived in his town to take over every aspect of preparations for her burial, from instructing on the ritual washing of the dead to making the arrangements for shipping her remains to Omdurman for burial. In Sudan, this is expected behavior following the death of a close friend or family member. In the US with its high costs of personal travel and tremendous distances, this behavior comes from the deepest aspects of al-mua'malat, service to others which Republicans view as the heart of their doctrine. "A group of brothers and sisters gave up their vacation time to come and help me at the darkest time in my life," this brother told me. This is evidence of the Republican community in the US not just settling down and assimilating in a diverse country, but of 
trying to establish and maintain in the US the religious norms that constructed their lives in Sudan.

Listening to multi-generational conversations of immigrant brothers and sisters over a Ramadan iftar in a Washington suburb reveals both the deepest and the quotidian concerns of the community: health reports of brotherhood members in Sudan and who has been hosting whom for other Ramadan meals; who is traveling where and why and by which route-which is also an information-seeking question. And what details are emerging from the struggle in Khartoum over a new government, its policies and primary actors. As the new government asserted itself in more recent months, this line of conversation focused on the phenomenon of Sudanese Americans accepting cabinet posts from their place of exile in the US. There is pride in the tone of the conversation, emanating from individual's consciousness that they have mastered life in the complicated USA. The participants do not neglect to translate some of this dialogue for some of the US-born present, who have not necessarily mastered the mother tongue. Older members of the group may never exhibit confidence in either English or American culture; they are always acting properly, if not comfortably, and retain the closest of ties with as many members of this Sudanese community as they can. Virtually every Republican who was active in the days of the movement and now lives abroad does travel to the Motherland at least once every few years; some making an annual summer visit with their school-aged children.

I interviewed a Republican mother who had raised four children largely alone-her husband tried to maintain his successful career in Sudan and visited the US when he could. She talked of the children's father disciplining them over the phone-long distanceor trying to counsel and console her daughters when they were mocked by Sudanese diaspora girls (not Republican) who had heard various versions of popular rumors of misinterpretations of Republican belief and practice. American teenagers particularly want to be accepted and confronting this type of social behavior did have an impact on the unquestioned loyalty of Republican children in the US to their parents' spiritual beliefs.

Keeping ties to Sudan family members and particularly to news of the Republican Brotherhood there is a key part of Republican survival abroad. Social media is the key to this effort. As the dust settled on the disbanded sit-ins and killings related to the demonstrations for Freedom and Change in early July 2019, the death of a prominent Republican, Mohamed Majzoub, brought the movement and its diaspora together in grief. Members changed their profile pictures to his and videos of the burial were featured on Facebook pages. WhatsApp provided details of where his children and widow were for those who wished to travel to see them. A poignant encounter was recorded in a video from Doha, where Mohamed's sister lives with her husband. A Facebook page featured a long Republican jelsa in Doha filled with tributes to the deceased and the singing of the qasaid and chants which were always the basis of Republican communal devotion. Republicans all over the world commented on this page which became the centerpiece of Mohamed's memorial. An effort has been launched recently by shabab, Republican youth living in the US-primarily of college age-to meet their peers regularly using a Facebook page and its live meeting applications. The leader poses a question to the group and participants respond from all over the US, reminiscent of youth-oriented programming on Al Jazeera English, "The Stream."

Practice and perfection of the Republican ideology in Sudan and its diaspora varies primarily in its intensity. In the years following the execution of Mahmoud Mohamed Taha, the Republicans have looked inwards for answers to their spiritual questions. Many speak of missing their engagement in dawa or recruitment to the Republican ideology, a major element in the daily routine of Republicans during Mahmoud Mohammed Taha's lifetime. That their children are missing out on this experience-both Republicans in Sudan and abroad lament this-may be part of the distinctly different attitude about Republican thought held by Republican offspring abroad, neither propagated nor abandoned. And now that political questions surface, every Sudanese remains glued to their TV screens watching their new "medaniya" (civilian) government unfold, as the devastating regime of 
Omar ElBashir came to an end in 2019, following a revolution that came from the streets. The Republican Brotherhood had a kiosk to exhibit publications and tapes of lectures at the huge encampment that served as headquarters for this revolution until it was swept away in June of 2019. But a transitional civilian government did emerge, with the military retaining a strong role. A handful of Republicans have even been appointed to high civilian positions. But economic and political anxiety still dominate.

Among the Republicans we witness an interesting dynamic of leadership in which "you lead me as I lead you" and virtually everyone steps up to do what is needed to be done. The dramatic changes of 2019 have even caused some in the ja'alia of Republicans abroad to imagine going home to continue their wait for what is yet to come in the land that gave rise to their spiritual constitution. What remains clear after years of listening to Republicans abroad is that exposure to "other Islams" in their travels has not distracted them from the precision of thought they learned from Mahmoud Mohamed Taha. "Either this or the flood" (ima hatha aw altuwfan) was the heading of the flyer they distributed on the streets of Khartoum that led to Ustadh Mahmoud's execution.

Preserving the Republican-ness of their children is a priority and it seems-at least on the surface- to be a successful process. An undergraduate at a US college who grew up in a large Republican family told me, "I cannot separate my identity as Sudanese from my identity as 'Jumhouri.' It's like I am only Sudanese through the Jumhouri lens." Separating the social aspects of that identity from the spiritual would be a murkier task. But what remains fundamentally clear is that the Republican Brotherhood remains an important example of a moderate Muslim social movement dedicated to peace.

Funding: This research received no external funding.

Institutional Review Board Statement: Not applicable.

Informed Consent Statement: Informed consent was obtained from all participants in this study and study was approved by IRB of Ohio University in 2017.

Data Availability Statement: Not applicable.

Conflicts of Interest: The author declares no conflict of interest.

\section{References}

An-Na'im, Abdullahi. 1986. “Mahmoud Mohamed Taha and Constitutional Law Reform,". typescript.

Brown, Bentley. 2020. Revolution from Afar. (2020) Film, 90 minutes.

Howard, Steve. 1986. Mahmoud Mohamed Taha: A remarkable teacher in Sudan. Northeast African Studies 10: 1.

Howard, Steve. 2016a. Modern Muslims: A Sudan Memoir. Athens: Ohio University Press.

Howard, Steve. 2016b. The Republican Sisters of Sudan: Moving to the Front Lines of Islamic Social Change. Hawwa: Brill, vol. 14, pp. 20-52. Karrar, Ali Salih. 1992. The Sufi Brotherhoods in the Sudan. Evanston: Northwestern University Press.

McHugh, Neil. 1994. Holymen of the Blue Nile: The Making of an Arab-Islamic Community in the Nilotic Sudan, 1500-1850. Evanston: Northwestern University Press.

Qutb, Sayyid. 1990. Milestones. Indianapolis: American Trust.

Republican Brotherhood. 1978. Towards the Second Message of Islam. Omdurman: Republican Brotherhood.

Taha, Mahmoud Mohamed. 1975. Risalat-a-sala ("The Message of Prayer"). Omdurman: Republican Brotherhood.

Taha, Mahmoud Mohamed. 1987. The Second Message of Islam. Translated by Abdullahi An-Na'im. Syracuse: Syracuse University Press. First published in 1964.

Trimingham, J. Spencer. 1949. Islam in the Sudan. London: Oxford University Press.

Varisco, Daniel Martin. 2005. Islam Obscured: The Rhetoric of Anthropological Representation. New York: Palgrave. 